\title{
The Organizational Life Cycle: Review and Future Agenda
}

\author{
DOI: 10.12776/QIP.V22I3.1177
}

\author{
Michal Jirásek, Jan Bílek
}

Received: 12 October 2018 Accepted: 03 November 2018 Published: 30 November 2018

\begin{abstract}
Purpose: The review summarizes major research that contributed to the organizational life cycle theory, discusses major issues and contradictions of the theory and offers additional assumptions about the organizational life cycle. Based on that, it attempts to offer a future research agenda for the theory.

Methodology/Approach: The paper uses narrative review; the list of included life cycle models stems from previous summaries of the theory and subsequent snowball search through reference lists of individual reviewed papers.
\end{abstract}

Findings: The theory is rich with various life cycle models that nevertheless converge on some major characteristics. Organizational life cycle can be described with classical five stages: (i) founding, (ii) growth, (iii) maturity, (iv) decline, and (v) revival. However, the stages do not necessarily follow in such an order, and therefore the research establishes likely paths in their development. Also, it appears that growth rate (relative to a market) and change in formalism are major factors distinguishing in the theory individual stages.

Research Limitation/implication: Organizational life cycle theory is often neglected based on simplifying presumptions like determinism of organizational development. On the other hand, there is a growing evidence that factors stemming from particular life cycle stages alter organizational behavior and therefore should be considered in behavioral research on an organizational level.

Originality/Value of paper: The paper represents up to date review of major theoretical models from the perspective of the current state of the field. Since the theory flourished in 70's and 80's it is inevitably limited in some aspects. The new review may spark renewed interest in implications stemming from the theory and enrich analytical tools of management scholars.

Category: Literature review

Keywords: organizations; life cycle; review 


\section{INTRODUCTION}

Organizations change over time, not just in terms of their strategies, but also in their leadership, structure, innovativeness and many other areas. Most of these changes are subtle from the perspective of the overall life - the existence of the organization. However, some are part of distinguishable patterns that form individual stages of organizational life cycle. Similar to living organisms, organizations have also life cycles that are determined by their founding and eventual demise (or take-over). Although not preset from their birth, most organizations meet their end in the range of decades. For example, out of the twelve companies that constituted Dow Johns Industrial Average Index in 1896, only one - General Electric - still belongs to important U.S. companies and it is hard to consider it thriving. The rest at best lost their dominance, changed their main business areas, were broken by antitrust laws, or were frequently bought by other companies. Virtually any organization existing for several decades will go through a revival stage, be taken-over or merge, or demise.

Although demises of large organizations usually represent spectacular accounts of disintegrating competitive advantage, their founding and growth tell totally different stories. On the other hand, not many organizations reach maturity (Dodge and Robbins (1992) note several indications of this), often not meeting break-even point or being taken-over. Maturity itself can be represented by a huge variety of different forms in terms of organizational size, age, and many other dimensions.

Individual life cycle stages are characteristic by different issues faced by the organization, the fact that is important for organizational life cycle scholars (e.g., Lippitt and Schmidt, 1967) and represents the major contribution of the theory together with patterns of solutions usually adopted by organizations facing them. Nevertheless, the organizational life cycle is from its outset (Downs, 1967) a subject for substantive controversy. Its name alone can draw a picture that is helpful both for theorizing (by the use of analogies with life cycles of biological organisms) and criticism (by apparent differences between organizations and biological organisms).

Despite their presentation as a series of stages, organizational life cycle should not be considered strictly sequential and deterministic (in which we agree with e. g., Miller and Friesen, 1984; and Mintzberg, 1984). This misconception, shared not just by critiques but also a number of the literature's authors, may be one of the major reasons why organizational life cycle theory failed from favor in last decades, in stark contract to e.g., product life cycle assessment (Hellweg and Canals, 2014). Compared to products that are often replaced by their successors, organizations may go through several revival stages and their life span is relatively longer than life of their products.

The theory itself is characteristic for the wealth of differing theoretical concepts rather than consensus understanding of the organization's life stages (Dufour, Steane and Corriveau, 2018). We overview the major frameworks further in our 
work. Despite this fact, we argue that the literature contains a large share of similarity that we attempt to highlight later on in our work.

We believe that organizational life cycle theory may be helpful for numerous organizational researchers since organizations in different life cycle stages behave differently in e.g., capital structure decisions (La Rocca, La Rocca and Cariola, 2011) or market selection and its effects (Bellone et al., 2008). Acknowledging these differences across life cycle stages may, therefore, bring new insights into various research topics.

\section{ORGANIZATIONAL LIFE CYCLE REVIEW}

We conducted a standard literature review starting with the studies listed in reviews of Quinn and Cameron (1983) and Dufour, Steane and Corriveau (2018). Then using the snowball method we added several other studies that are cited in the papers we review. In the process, we focus on individual life cycle stages and their main characteristics as described by the authors. We summarize our findings in Table 1. It is important to note that the life cycle models presented in the table are not independent of each other. There was a rich cross-fertilization among authors (e.g., Jawahar and McLaughlin, 2001) that may be the cause of some convergence in later years.

Although the apparent difference between individual models lies in the number of stages, there are more subtle differences we highlight in the text below. Some models focus on growth part of the cycle only and end up with maturity (these are usually early ones, e.g., Downs 1967; Lippitt and Schmidt, 1967; or Scott, 1971). We base our review on the seminal classification of Miller and Friesen (1984) that distinguish five stages of organizational life cycle: (i) birth; (ii) growth; (iii) maturity; (iv) revival; and (v) decline.

\subsection{Birth - Founding}

Birth or founding stage of organizational life cycle is characteristic by the organizational struggle for survival (e.g., Lippitt and Schmidt, 1967; Churchill and Lewis, 1983) mediated by product development and acquisition of necessary resources (Jawahar and McLaughlin, 2001). Typically, the organization generates negative cash during these times (Scott and Bruce, 1983). At this stage, the organization does not have any power over its external environment and therefore needs to adapt to it (Lyden, 1975). The structure of the organization is simple, often informal and with centralized leadership (e.g., Smith, Mitchell and Summer, 1985; Gray and Ariss, 1985). In the relationship to stakeholders (Jawahar and McLaughlin, 2001), the organization proactively manages these with shareholders, creditors and customers, accommodates to employees and suppliers, while being reactive or defensive in relationships to the other groups.

While this initial stage is a part of models of all the reviewed authors, some devote more attention to it and paint a more fine-grained picture of what happens 
during, or even before, the founding of the organization. The most typical case is Torbert (1984) whose first four stages can be classified into founding - fantasies, investments, determinations, and experiments. While this level of detail may be beneficial for a study of organizational founding, they offer possibly a too rich picture, especially in contrast to later stages.

\subsection{Growth}

When the organization succeeds in creating its distinctive competitive advantage, growth in sales and market share follows (e.g., Kazanjian, 1988). Now, the focus switches to managing relatively rapid expansion (Scott and Bruce, 1987), with production and resources issues at the forefront (Flamholtz, 1990; 1995). As we discuss later on, cash generation can be either still negative or reach break-even and be positive, depending on other factors. As the demand typically exceeds supply, the organization is rather inward oriented to its production and proactively approaches creditors, employees, suppliers, and trade associations (Jawahar and McLaughlin, 2001). The structure and processes are gradually becoming formal with the organization adapting U-form structure (e.g., Gaibraith, 1982). Despite increasing decentralization and delegation (Greiner, 1972), the company usually keeps entrepreneurial spirit at this time (Adizes, 1979).

Similar to the founding stage, some authors also distinguish several growth stages. This time, we consider them much more helpful since growth pattern of organizations may differ and some of them may not reach that "rapid" growth as envisioned in the classical life cycle model of Downs (1967) and some other authors later (e.g., Smith, Mitchell and Summer, 1985; Hanks, 1990).

Early growth stage (Scott and Bruce, 1987) follows the transition from individualistic to more administrative entrepreneurial style. Typically, the organization either continues with negative cash generation or archives break-even. A simple structure is already in place.

Late growth stage (Adizes, 1979) is characteristic by the struggle between further grow and the need for formalization of increasingly complex processes. At this time, more systematic management is needed, which interferes with a previously unbounded growth orientation. Also, increasing competitive pressures may slow down further development (Dodge and Robbins, 1992). With slowing growth and more formalized nature, the organization stabilizes and matures.

\subsection{Maturity}

The organization that achieves maturity is stabilized in terms of the need for radical changes. It usually grows foreseeably (Adizes, 1979) and at market rate (Kazanjian, 1988). The organization now lives on past successes, keeps it direction and focuses on exploitation (Dufour, Steane and Corriveau, 2018). At this time, the structure and processes are formalized as management is separated 
from ownership (Churchill and Lewis, 1983; Miller and Friesen, 1984) - which, however, may not be the case of small- and medium-sized organizations. Scott and Bruce (1987) point to the adoption of M-form by some organizations, while other authors (Miller and Friesen, 1984; Hanks, 1990; Hanks et al., 1994) link this form to revival stage. However, similar to the separation of management of ownership, this question is more typical for large organizations. At this stage, the organization should be at its temporal profit peak (Scott and Bruce, 1987).

In this case, authors describe arguably the broadest array of individual maturity forms, typically in relationship to the topic they want to cover over the life cycle (e.g., the growth of bureaucracy as Adizes, 1979). In these cases, mature stages are ordered from an ending growth to start of a decline and are characteristic by decreasing innovativeness of the organization (its ability to renew itself) and increasing formalization turning the organization into the bureaucracy full of political struggles (Mintzberg, 1984). With the competitive advantage that starts to slowly erode, the organization enters either revival stage in which it reinvents its business or decline stage in which it struggles with the need for a change.

\subsection{Revival}

Revival stage represents a renewed focus of the organization on exploration of new possibilities. In this case, adoption of M-form (Miller and Friesen, 1984; Hanks, 1990; Hanks et al., 1994) may happen as the organization keeps both its old and new business lines separated from each other. The co-existence of both businesses is virtually necessary for all except small organizations unless they want to go through the drastic cut into their stakeholders' ties. Also, new resources are brought to the organization, represented by people skilled in R\&D, engineering, planning or performance analysis (Miller and Friesen, 1984) to help the revival to happen.

More risk-taking happens at this stage (Jawahar and McLaughlin, 2001), although not blind, but rather informed and analytical (Miller and Friesen, 1984). Of course, there is opposition to a change by those negatively affected by it (Gray and Ariss, 1985), but this does not prevail unless the organization enters the decline stage. The organization that successfully goes through revival stage experience further growth or become stabilized in mature stage once more.

\subsection{Decline and Demise}

Growing adversity of external environment is a common reason for the organization to enter decline stage (Miller and Friesen, 1984), together with growing internal rigidity or even strife resulting with overall bureaucracy (Adizes, 1979). Attempts to change as strongly opposed (Gray and Ariss, 1985) or are not successful. The focus shifts again to survival (Hanks, 1990; Hanks et al., 1994). The competitive advantage of the organization erodes resulting in decreasing sales (Hanks, 1990; Hanks et al., 1994) and loss of market position (Lester, Parnell and Carraher, 2003). The organization can be caught in a vicious 
cycle of insufficient resources making necessary investment impossible which result in the lower appeal of its products and a further decrease in resources (Miller and Friesen, 1984).

Despite the fact that the decline stage is usually the last one in organizational life cycle models, we do not consider it to be necessarily the last in the life of the organization. From our perspective, the decline may end up either negatively for the future organizational existence when it leads to the demise or the loss of independence or it may turn into successful revival.

\subsection{Life cycle Irregularities}

Although life cycle may describe the general development of the organization and revival stage may explain why some organizations return to growth after achieving maturity or even decline, there are still numerous and frequent cases when organizations follow different paths. The two cases we want to discuss further are: (i) timing of break-even and (ii) timing of decline and demise.

Timing of break-even. Boundary state that is characteristic by break-even, is by some authors assumed to follow founding stage (e.g., Scott and Bruce, 1987; Churchill and Lewis, 1983), while others consider rather as a result of the decision to slow down the growth (e.g., Adizes, 1979). Both cases are possible in the reality, the first often common in traditional and stable sectors, where the organization must relatively quickly prove its profitability to obtain further resources for scalability and growth; the second is frequent in rapidly evolving high-risk sectors, where huge gains can be made by growing quickly (digital technologies). Therefore, we believe that timing of break-even is contingent to the environment of the organization, which likely interferes with the life cycle of environment-industry itself (which apparently affects organizational behavior, e.g., Verreynne and Meyer, 2010).

Timing of decline and demise. Taken as sequential, life cycle models (see Tab. 1) predicts that organizational demise follows the decline of mature organizations. However, as, e.g., Mintzberg (1984) points out, demise is frequent among new organizations as well. He highlights the importance of a leader and reliance of coordination mechanisms on her/him. Any absence may thus lead to disintegration and demise. Another major reason of demise stems from an inability of the organization to generate resources to sustain its operation (in case of financial resources resulting to bankruptcy, take-over etc.).

One of the works that also focus on decline and demise of organizations in their earlier stages is Adizes (1979) who lists reasons for demise in all of his stages: (i) aborted idea; (ii) infant mortality - resulting from fragility of the organization in face of major mistakes; (iii) founder's trap - when founder is not willing to depersonalize organization; (iv) divorce - founding partner or group of people decide to leave the organization; and (v) growing formalism and inner orientation. 
Table 1 - Overview of Reviewed Organizational Life Cycle Studies

\begin{tabular}{|c|c|c|c|c|c|}
\hline Authors & \multicolumn{5}{|c|}{ Stages of life cycle } \\
\hline $\begin{array}{l}\text { Downs } \\
\text { (1967) }\end{array}$ & $\begin{array}{l}\text { 1. Struggle for autonomy } \\
\text { (effort to break through, } \\
\text { gain resources and } \\
\text { independence) }\end{array}$ & $\begin{array}{l}\text { 2. Rapid growth } \\
\text { (emphasis on innovation and } \\
\text { expansion) }\end{array}$ & $\begin{array}{l}\text { 3. Deceleration } \\
\text { (coordination issues due to size } \\
\text { and complexity, formalization, } \\
\text { conservatism) }\end{array}$ & & \\
\hline $\begin{array}{l}\text { Lippitt and } \\
\text { Schmidt } \\
(1967)\end{array}$ & $\begin{array}{l}\text { 1. Birth } \\
\text { (goal to survive, risk issues } \\
\text { are discussed, one leader) }\end{array}$ & $\begin{array}{l}\text { 2. Youth } \\
\text { (goal to stabilize, systematic } \\
\text { control and collective } \\
\text { decision making) }\end{array}$ & $\begin{array}{l}\text { 3. Maturity } \\
\text { (adaptability focus, search for new } \\
\text { opportunities) }\end{array}$ & & \\
\hline Scott (1971) & $\begin{array}{l}\text { 1. Stage } 1 \\
\text { (one leader, informal } \\
\text { structure) }\end{array}$ & $\begin{array}{l}\text { 2. Stage } 2 \\
\text { (formalized U-form } \\
\text { structure) }\end{array}$ & $\begin{array}{l}\text { 3. Stage } 3 \\
\text { (search for new opportunities, } \\
\text { diversification, formalized M- } \\
\text { form structure) }\end{array}$ & & \\
\hline $\begin{array}{l}\text { Greiner } \\
(1972)\end{array}$ & $\begin{array}{l}\text { 1. Phase } 1 \\
\text { (goal to produce and sell, } \\
\text { informal structure, maximal } \\
\text { founders' commitment) }\end{array}$ & $\begin{array}{l}\text { 2. Phase } 2 \\
\text { (focus on efficiency, } \\
\text { centralized U-form } \\
\text { structure, IT systems } \\
\text { implementation) }\end{array}$ & $\begin{array}{l}\text { 3. Phase } 3 \\
\text { (focus on growth on the market } \\
\text { and market extension, } \\
\text { decentralization of structure, } \\
\text { delegation) }\end{array}$ & $\begin{array}{l}\text { 4. Phase } 4 \\
\text { (consolidation, creation of } \\
\text { product teams, high level of } \\
\text { formalization and control) }\end{array}$ & $\begin{array}{l}\text { 5. Phase } 5 \\
\text { (focus on problem solutions } \\
\text { and innovations, matrix } \\
\text { structure, simplification of } \\
\text { control systems) }\end{array}$ \\
\hline \multirow[t]{2}{*}{$\begin{array}{l}\text { Torbert } \\
\text { (1974) }\end{array}$} & $\begin{array}{l}\text { 1. Fantasies } \\
\text { (formation of individual } \\
\text { visions, informal } \\
\text { communication) }\end{array}$ & $\begin{array}{l}\text { 2. Investments } \\
\text { (full commitment to form an } \\
\text { organization, first } \\
\text { relationships) }\end{array}$ & $\begin{array}{l}\text { 3. Determinations } \\
\text { (goal clarification, creation of } \\
\text { both formal and informal } \\
\text { contracts) }\end{array}$ & $\begin{array}{l}\text { 4. Experiments } \\
\text { (testing alternative legal, } \\
\text { administrative, production, } \\
\text { planning and other } \\
\text { structures) }\end{array}$ & $\begin{array}{l}\text { 5. Predefined productivity } \\
\text { (focus on predefined goals, } \\
\text { sustainability of a product as } \\
\text { a success measure, forming } \\
\text { of standards) }\end{array}$ \\
\hline & $\begin{array}{l}\text { 6. Openly chosen structure } \\
\text { (long-term orientation, } \\
\text { horizontal differentiation, } \\
\text { cooperation across levels, } \\
\text { innovative methods) }\end{array}$ & $\begin{array}{l}\text { 7. Foundational community } \\
\text { (focus on shared values, } \\
\text { increasing importance of } \\
\text { organizational culture) }\end{array}$ & $\begin{array}{l}\text { 8. Liberating disciplines } \\
\text { (removal of boundaries between } \\
\text { an organization and a market, } \\
\text { search for new opportunities) }\end{array}$ & & \\
\hline
\end{tabular}




\begin{tabular}{|c|c|c|c|c|c|}
\hline Authors & \multicolumn{5}{|c|}{ Stages of life cycle } \\
\hline $\begin{array}{l}\text { Lyden } \\
(1975)\end{array}$ & $\begin{array}{l}\text { 1. First stage } \\
\text { (focus on adaptation to an } \\
\text { external environment) }\end{array}$ & $\begin{array}{l}\text { 2. Second stage } \\
\text { (focus on an acquisition of } \\
\text { necessary resources) }\end{array}$ & $\begin{array}{l}\text { 3. Third stage } \\
\text { (focus on goal attainment) }\end{array}$ & $\begin{array}{l}\text { 4. Fourth stage } \\
\text { (focus on } \\
\text { institutionalization) }\end{array}$ & \\
\hline $\begin{array}{l}\text { Katz and } \\
\text { Kahn (1978) }\end{array}$ & $\begin{array}{l}\text { 1. Primitive system stage } \\
\text { (cooperation based on } \\
\text { shared goals and } \\
\text { expectations) }\end{array}$ & $\begin{array}{l}\text { 2. Stable organization stage } \\
\text { (coordination and } \\
\text { formalization) }\end{array}$ & $\begin{array}{l}\text { 3. Elaborative supportive } \\
\text { structures stage } \\
\text { (improvement and creation of } \\
\text { systems) }\end{array}$ & & \\
\hline \multirow[t]{2}{*}{$\begin{array}{l}\text { Adizes } \\
(1979)\end{array}$} & $\begin{array}{l}\text { 1. Courtship } \\
\text { (formation of intentions of } \\
\text { future founders) }\end{array}$ & $\begin{array}{l}\text { 2. Infant organization } \\
\text { (creation of an organization, } \\
\text { no systematic management, } \\
\text { one leader, high uncertainty, } \\
\text { goal to acquire resources } \\
\text { and survive) }\end{array}$ & $\begin{array}{l}\text { 3. The go-go stage } \\
\text { (fast growth, partial delegation of } \\
\text { leader's power, gradual } \\
\text { formalization) }\end{array}$ & $\begin{array}{l}\text { 4. Adolescent organization } \\
\text { (need of further } \\
\text { formalization and systematic } \\
\text { management, conflict } \\
\text { between } \\
\text { formalization/stabilization } \\
\text { and growth orientation) }\end{array}$ & $\begin{array}{l}\text { 5. Prime organization } \\
\text { (stable and foreseeable } \\
\text { growth, overall stabilization) }\end{array}$ \\
\hline & $\begin{array}{l}\text { 6. Mature organization } \\
\text { (standardized processes, } \\
\text { focus on performance, } \\
\text { decreasing innovativeness } \\
\text { and adaptability, routine } \\
\text { behavior) }\end{array}$ & $\begin{array}{l}\text { 7. Aristocracy } \\
\text { (lack of innovativeness, life } \\
\text { on past success, growth by } \\
\text { price increases) }\end{array}$ & $\begin{array}{l}\text { 8. Early bureaucracy } \\
\text { (price increase no longer working, } \\
\text { search for causes of problems and } \\
\text { internal struggles, further } \\
\text { decrease) }\end{array}$ & $\begin{array}{l}\text { 9. Bureaucracy } \\
\text { (growth in formalization } \\
\text { instead of innovation, focus } \\
\text { on norms and rules) }\end{array}$ & $\begin{array}{l}\text { 10. Death } \\
\text { (nonfunctional organization } \\
\text { cease to exist) }\end{array}$ \\
\hline $\begin{array}{l}\text { Kimberly } \\
(1979)\end{array}$ & $\begin{array}{l}\text { 1. First stage } \\
\text { (acquisition of resources, } \\
\text { creation of ideology) }\end{array}$ & $\begin{array}{l}\text { 2. Second stage } \\
\text { (acquisition of sufficient } \\
\text { support, employee } \\
\text { acquisition) }\end{array}$ & $\begin{array}{l}\text { 3. Third stage } \\
\text { (identity formation, shared spirit, } \\
\text { strong commitment) }\end{array}$ & $\begin{array}{l}\text { 4. Fourth stage } \\
\text { (formalized structure, } \\
\text { adoption of rules, } \\
\text { conservative approach, } \\
\text { stabilization of external } \\
\text { relationships) }\end{array}$ & \\
\hline
\end{tabular}




\begin{tabular}{|c|c|c|c|c|c|}
\hline Authors & \multicolumn{5}{|c|}{ Stages of life cycle } \\
\hline $\begin{array}{l}\text { Gaibraith } \\
\text { (1982) }\end{array}$ & $\begin{array}{l}\text { 1. Proof of principle } \\
\text { prototype } \\
\text { (goal in product } \\
\text { development, } \\
\text { nonbureaucratic climate, } \\
\text { informal processes and } \\
\text { structure) }\end{array}$ & $\begin{array}{l}\text { 2. Model shop } \\
\text { (goal in production, } \\
\text { nonbureaucratic climate, } \\
\text { informal processes, } \\
\text { functions and hierarchy } \\
\text { begin) }\end{array}$ & $\begin{array}{l}\text { 3. Start-up volume production } \\
\text { (goal in mass production, formal } \\
\text { processes, U-form, centralized } \\
\text { division of labor) }\end{array}$ & $\begin{array}{l}\text { 4. Natural growth } \\
\text { (goal in profitability, formal } \\
\text { control, U-form, } \\
\text { decentralized) }\end{array}$ & $\begin{array}{l}\text { 5. Strategic maneuvering } \\
\text { (goal in dominating a niche, } \\
\text { plans and profit centers, } \\
\text { matrix structure) }\end{array}$ \\
\hline $\begin{array}{l}\text { Churchill } \\
\text { and Lewis } \\
(1983)\end{array}$ & $\begin{array}{l}\text { 1. Existence } \\
\text { (one leader, focus on } \\
\text { survival, minimal } \\
\text { formalization) }\end{array}$ & $\begin{array}{l}\text { 2. Survival } \\
\text { (simple structure, focus on } \\
\text { break-even or at least } \\
\text { survival) }\end{array}$ & $\begin{array}{l}\text { 3. Success } \\
\text { (separation of ownership and } \\
\text { management, good economic } \\
\text { conditions, question whether grow } \\
\text { or stabilize) }\end{array}$ & $\begin{array}{l}\text { 4. Take-off } \\
\text { (decentralization, high level } \\
\text { of strategic and operational } \\
\text { planning, systematic } \\
\text { control) }\end{array}$ & $\begin{array}{l}\text { 5. Resource maturity } \\
\text { (decentralization, high level } \\
\text { of strategic and operational } \\
\text { planning, synergies and } \\
\text { resource availability, risk of } \\
\text { stagnation and low } \\
\text { innovativeness) }\end{array}$ \\
\hline $\begin{array}{l}\text { Quinn and } \\
\text { Cameron } \\
\text { (1983) }\end{array}$ & $\begin{array}{l}\text { 1. Entrepreneurial stage } \\
\text { (abundancy of ideas, } \\
\text { minimal planning and } \\
\text { coordination, niche } \\
\text { occupation) }\end{array}$ & $\begin{array}{l}\text { 2. Collectivity stage } \\
\text { (informal communication } \\
\text { and structure, collective } \\
\text { decision making, } \\
\text { innovativeness and } \\
\text { commitment) }\end{array}$ & $\begin{array}{l}\text { 3. Formalization and control stage } \\
\text { (formalization of rules, structure } \\
\text { stabilization, performance focus) }\end{array}$ & $\begin{array}{l}\text { 4. Elaboration of structure } \\
\text { stage } \\
\text { (decentralization, } \\
\text { adaptability focus, } \\
\text { expansion) }\end{array}$ & \\
\hline $\begin{array}{l}\text { Scott and } \\
\text { Bruce } \\
(1987)\end{array}$ & $\begin{array}{l}\text { 1. Inception } \\
\text { (entrepreneurial } \\
\text { individualistic style, no } \\
\text { structure, negative cash } \\
\text { generation, focus on market } \\
\text { and product) }\end{array}$ & $\begin{array}{l}\text { 2. Survival } \\
\text { (entrepreneurial } \\
\text { administrative style, simple } \\
\text { organization structure, } \\
\text { negative/break-even cash } \\
\text { generation, focus on } \\
\text { revenues and expenses) }\end{array}$ & $\begin{array}{l}\text { 3. Growth } \\
\text { (entrepreneurial coordinative } \\
\text { style, centralized U-shape form, } \\
\text { positive but reinvested cash } \\
\text { generation, focus on managed } \\
\text { growth and ensuring resources) }\end{array}$ & $\begin{array}{l}\text { 4. Expansion } \\
\text { (professional administrative } \\
\text { style, decentralized U-shape } \\
\text { form, cash generation } \\
\text { positive with small } \\
\text { dividend, focus on financing } \\
\text { growth and maintaining } \\
\text { control) }\end{array}$ & $\begin{array}{l}\text { 5. Maturity } \\
\text { (watchdog management } \\
\text { style, decentralized U-/M- } \\
\text { shape form, cash generation } \\
\text { with higher dividend, focus } \\
\text { on productivity and expense } \\
\text { control) }\end{array}$ \\
\hline
\end{tabular}




\begin{tabular}{|c|c|c|c|c|c|}
\hline \multirow{2}{*}{$\begin{array}{l}\text { Authors } \\
\text { Mintzberg } \\
\text { (1984) }\end{array}$} & \multicolumn{5}{|c|}{ Stages of life cycle } \\
\hline & $\begin{array}{l}\text { 1. Formation } \\
\text { (autocracy politics - } \\
\text { personalized internal } \\
\text { coalition and passive } \\
\text { external coalition, strong } \\
\text { leader position) }\end{array}$ & $\begin{array}{l}\text { 2. Development } \\
\text { (either (i) instrument politics } \\
\text { - bureaucratic control } \\
\text { though management, or (ii) } \\
\text { missionary politics - } \\
\text { institutionalized ideology) }\end{array}$ & $\begin{array}{l}\text { 3. Maturity } \\
\text { (either (i) closed system politics - } \\
\text { a group of administrators as a } \\
\text { center of power, or (ii) } \\
\text { meritocracy politics - power based } \\
\text { on skills and knowledge) }\end{array}$ & $\begin{array}{l}\text { 4. Decline } \\
\text { (politicized organization) }\end{array}$ & \\
\hline $\begin{array}{l}\text { Miller and } \\
\text { Friesen } \\
(1984)\end{array}$ & $\begin{array}{l}\text { 1. Birth } \\
\text { (simple structure, one } \\
\text { leader, minimal } \\
\text { formalization) }\end{array}$ & $\begin{array}{l}\text { 2. Growth } \\
\text { (more complex structure, U- } \\
\text { form structure, some } \\
\text { formalization, focus on } \\
\text { growth and diversification) }\end{array}$ & $\begin{array}{l}\text { 3. Maturity } \\
\text { (conservatism, focus on } \\
\text { performance and profitability, } \\
\text { separation of ownership and } \\
\text { management, systematic control } \\
\text { and planning, centralization) }\end{array}$ & $\begin{array}{l}\text { 4. Revival } \\
\text { (diversification, } \\
\text { innovativeness, M-form } \\
\text { structure, centralized } \\
\text { strategy, decentralized } \\
\text { operational decision } \\
\text { making) }\end{array}$ & $\begin{array}{l}\text { 5. Decline } \\
\text { (centralized decision } \\
\text { making, conservatism and } \\
\text { risk aversion, focus on } \\
\text { internal problems) }\end{array}$ \\
\hline $\begin{array}{l}\text { Smith, } \\
\text { Mitchell and } \\
\text { Summer } \\
(1985)\end{array}$ & $\begin{array}{l}\text { 1. Inception } \\
\text { (informal structure and } \\
\text { communication, limited and } \\
\text { nonsystematic planning, ad } \\
\text { hoc decision making, } \\
\text { continuous evolution) }\end{array}$ & $\begin{array}{l}\text { 2. High growth } \\
\text { (formalization and } \\
\text { centralization, budget } \\
\text { planning, analytical decision } \\
\text { making, rapid growth) }\end{array}$ & $\begin{array}{l}\text { 3. Maturity } \\
\text { (formalization and centralization, } \\
\text { strategic planning, rules, growth } \\
\text { slows down or turns to decrease) }\end{array}$ & & \\
\hline $\begin{array}{l}\text { Gray and } \\
\text { Ariss (1985) }\end{array}$ & $\begin{array}{l}\text { 1. Birth and early growth } \\
\text { (little or no formal structure, } \\
\text { one leader, uncertainty in } \\
\text { the market, focus on internal } \\
\text { adaptation) }\end{array}$ & $\begin{array}{l}\text { 2. Maturity } \\
\text { (delegation to management, } \\
\text { bureaucracy, focus on } \\
\text { market share, manage } \\
\text { external environment, } \\
\text { formalization of rules, } \\
\text { conflicts between subunits) }\end{array}$ & $\begin{array}{l}\text { 3. Decline or redevelopment } \\
\text { (hostile environment, high } \\
\text { incentives to change and } \\
\text { opposition against change, } \\
\text { intensive politics) }\end{array}$ & & \\
\hline
\end{tabular}




\begin{tabular}{|c|c|c|c|c|c|}
\hline Authors & \multicolumn{5}{|c|}{ Stages of life cycle } \\
\hline $\begin{array}{l}\text { Kazanjian } \\
(1988)\end{array}$ & $\begin{array}{l}\text { 1. Conception and } \\
\text { development } \\
\text { (non-existing structure and } \\
\text { minimal formalization, goal } \\
\text { to transform idea into } \\
\text { reality, focus on product } \\
\text { development) }\end{array}$ & $\begin{array}{l}\text { 2. Commercialization } \\
\text { (structure formation, U-form } \\
\text { structure, goal to market a } \\
\text { functioning product) }\end{array}$ & $\begin{array}{l}\text { 3. Growth } \\
\text { (further development of structure, } \\
\text { focus on large scale } \\
\text { manufacturing/selling/distribution, } \\
\text { growth of sales and market share) }\end{array}$ & $\begin{array}{l}\text { 4. Stability } \\
\text { (formalized structure, } \\
\text { norms, focus on preserving a } \\
\text { good market position, } \\
\text { growth at market pace, } \\
\text { separation of ownership and } \\
\text { management) }\end{array}$ & \\
\hline $\begin{array}{l}\text { Hanks } \\
(1990), \\
\text { Hanks et al. } \\
(1994)\end{array}$ & $\begin{array}{l}\text { 1. Start-up stage } \\
\text { (simple structure, } \\
\text { centralization) }\end{array}$ & $\begin{array}{l}\text { 2. Expansion } \\
\text { (fast growth, growth in } \\
\text { capacity, incremental } \\
\text { innovations, U-form } \\
\text { structure) }\end{array}$ & $\begin{array}{l}\text { 3. Consolidation } \\
\text { (slower growth, systematic control } \\
\text { and planning, focus on } \\
\text { performance and profit, process } \\
\text { innovation, participative } \\
\text { leadership) }\end{array}$ & $\begin{array}{l}\text { 4. Revival/Diversification } \\
\text { (fast growth, diversification, } \\
\text { M-form structure, } \\
\text { decentralization and } \\
\text { formalization) }\end{array}$ & $\begin{array}{l}\text { 5. Decline } \\
\text { (decreasing sales, focus on } \\
\text { demise avoidance, need for } \\
\text { leaders and reorganization } \\
\text { with focus on decrease in } \\
\text { bureaucracy) }\end{array}$ \\
\hline $\begin{array}{l}\text { Flamholtz } \\
(1990 ; 1995)\end{array}$ & $\begin{array}{l}\text { 1. New venture } \\
\text { (defining market and } \\
\text { developing product, focus } \\
\text { on survival) } \\
\text { 6. Integration } \\
\text { (integration of various units, } \\
\text { while keeping benefits of } \\
\text { partial decentralization) }\end{array}$ & $\begin{array}{l}\text { 2. Expansion } \\
\text { (focus on operational system } \\
\text { and organizational } \\
\text { resources) } \\
\text { 7. Decline-revitalization } \\
\text { (focus on organizational } \\
\text { renewal) }\end{array}$ & $\begin{array}{l}\text { 3. Professionalization } \\
\text { (development of management } \\
\text { systems) }\end{array}$ & $\begin{array}{l}\text { 4. Consolidation } \\
\text { (focus on organizational } \\
\text { culture) }\end{array}$ & $\begin{array}{l}\text { 5. Diversification } \\
\text { (search for new markets and } \\
\text { products, re-introduction of } \\
\text { entrepreneurial spirit) }\end{array}$ \\
\hline $\begin{array}{l}\text { Dodge and } \\
\text { Robbins } \\
(1992)\end{array}$ & $\begin{array}{l}\text { 1. Formation } \\
\text { (goal to transform idea into } \\
\text { reality, one leader, selective } \\
\text { strategy) }\end{array}$ & $\begin{array}{l}\text { 2. Early growth } \\
\text { (remarkable growth, } \\
\text { uncertain environment - } \\
\text { need for adaptation, gradual } \\
\text { formalization of a structure) }\end{array}$ & $\begin{array}{l}\text { 3. Later growth } \\
\text { (slowing growth, competitive } \\
\text { pressures, question whether } \\
\text { growth or stabilize, advance in } \\
\text { systematic control and planning) }\end{array}$ & $\begin{array}{l}\text { 4. Stability } \\
\text { (stability or stagnation, } \\
\text { bureaucracy, demise or } \\
\text { renewal in innovativeness) }\end{array}$ & \\
\hline
\end{tabular}




\begin{tabular}{|c|c|c|c|c|c|}
\hline Authors & \multicolumn{5}{|c|}{ Stages of life cycle } \\
\hline $\begin{array}{l}\text { Jawahar and } \\
\text { McLaughlin } \\
\text { (2001) }\end{array}$ & $\begin{array}{l}\text { 1. Start-up } \\
\text { (focus on development and } \\
\text { implementation of business } \\
\text { plan, proactive shareholders, } \\
\text { creditors and customers } \\
\text { focus, resource acquisition, } \\
\text { entering market, failure as } \\
\text { reference point - risk- } \\
\text { seeking) }\end{array}$ & $\begin{array}{l}\text { 2. Emerging growth } \\
\text { (risk aversion, focus } \\
\text { especially on creditors, } \\
\text { employees, suppliers and } \\
\text { trade associations) }\end{array}$ & $\begin{array}{l}\text { 3. Mature } \\
\text { (risk-aversion, overconfidence of } \\
\text { success, proactive stakeholder } \\
\text { management - except for } \\
\text { creditors) }\end{array}$ & $\begin{array}{l}\text { 4. Decline/Transition } \\
\text { (risk-seeking, proactive } \\
\text { management of } \\
\text { shareholders, creditors and } \\
\text { customers) }\end{array}$ & \\
\hline $\begin{array}{l}\text { Lester, } \\
\text { Parnell and } \\
\text { Carraher } \\
(2003)\end{array}$ & $\begin{array}{l}\text { 1. Existence } \\
\text { (focus on survival, } \\
\text { centralization) }\end{array}$ & $\begin{array}{l}\text { 2. Survival } \\
\text { (focus on growth attainment, } \\
\text { gradual formalization) }\end{array}$ & $\begin{array}{l}\text { 3. Success } \\
\text { (high level of formalization and } \\
\text { bureaucracy, delegation) }\end{array}$ & $\begin{array}{l}\text { 4. Renewal } \\
\text { (goal to achieve leaner } \\
\text { organization, support of } \\
\text { innovativeness, possibly } \\
\text { matrix structure, } \\
\text { decentralization) }\end{array}$ & $\begin{array}{l}\text { 5. Decline } \\
\text { (loss of market position, } \\
\text { decision making centralized } \\
\text { again) }\end{array}$ \\
\hline $\begin{array}{l}\text { Dufour, } \\
\text { Steane and } \\
\text { Corriveau } \\
(2018)\end{array}$ & $\begin{array}{l}\text { 1. Acting the future } \\
\text { (entrepreneurial spirit, } \\
\text { innovativeness, gap between } \\
\text { vision for the future and } \\
\text { current state) }\end{array}$ & $\begin{array}{l}\text { 2. Reflecting on the past } \\
\text { (development of rules for } \\
\text { success while trying to } \\
\text { remain entrepreneurial, } \\
\text { performance focus) }\end{array}$ & $\begin{array}{l}\text { 3. Acting on the past } \\
\text { (keeping direction without sudden } \\
\text { changes, exploitation focus) }\end{array}$ & $\begin{array}{l}\text { 4. Thinking the future } \\
\text { (reflection of current } \\
\text { position and thinking about } \\
\text { a future one) }\end{array}$ & \\
\hline
\end{tabular}




\section{LIFE CYCLE MODEL}

One of the major setbacks of organizational life cycle theory is its focus on large organizations. Although birth-founding and growth stages are experienced by almost every successful mature organization, nature of growth much affects resulting maturity. Mature organizations do not necessarily be big in size and that influences numerous characteristics ascribed by the authors to mature organizations. For example, separation of ownership and management (as assumed by Churchill and Lewis, 1983; Miller and Friesen, 1984) is frequently not the case for some SMEs or family firms (Brunninge, Nordqvist and Wiklund, 2007; Burkart, Panunzi and Shleifer, 2003). Despite the fact that the reviewed models exhibit rather growing complexity over time, we believe that this issue has to be addressed when working with life cycle models in a subsequent research (beside above-mentioned separation, it is arguably also formalization, structure, size etc.).

In this section, we want to present a model that synthesizes previous literature. We do not aim to bring an entirely new view of the life cycle since we believe that the literature already depicted a picture that corresponds to the abstracted reality. Instead, we want to fill in our answers to major reservations we have towards previous models.

One major assumption that simplifies our model is that we do not expect the organization to be taken-over. The organization can be virtually taken-over in any stage of its life cycle, therefore it does not make sense to incorporate it directly to the model, although it is something a reader should bear in mind when thinking of organizational development. Also, we argue that these situations hardly affects organizational behavior until the last moment.

We consider five-stage model of Miller and Friesen (1984) well fitting the situation. Since we criticize some aspects of previous models (assumptions about structure etc.), we consider growth and level of formalism to be the key characteristics that distinguish individual stages from each other:

Proposition 1. The organization in its life cycle experiences (i) positive growth that is faster than market rate in growth stage; (ii) positive growth at market rate or stagnation in maturity stage; and (iii) negative growth in decline stage. For both founding and revival stages, there is not a distinguishable pattern of growth.

Proposition 2. The organization in its life cycle experiences rising levels of formalism from the founding stage, through growth and maturity, to decline stage. During the revival stage, the level of formalism decreases from previous levels.

In the case of growth stage, we expect it to take shape of S-curve, meaning that after founding, the organization that does not experience demise first go through 
slow growth, followed by rapid growth and later slower growth when it experiences the transition to maturity stage.

Proposition 3. The organization growth in growth stage resembles S-curve with the relatively slower rate of growth in early and late part of the stage and rapid rate of growth in the middle part of the stage.

Although exceptions in other stages are plausible, we assume that organizations, besides following linear development of their life cycle, are also likely to demise right after founding. Otherwise, we expect them to demise only after going through decline stage. On the other hand, decline stage is not necessary for the organization to enter revival. Also, we consider revival to be a synonym for a successful change, while an unsuccessful change is a part of maturity and later decline stage. This largely fits the pattern observed among organizations by Miller and Friesen (1984). We illustrate the life cycle in Figure 1, where we also add examples to individual paths from the IT sector.

Proposition 4. Following its (i) founding, the organization can either demise or enter growth stage; from (ii) the growth stage, the organization can enter either decline or maturity stages; from (iii) maturity, the organization can enter either decline or revival stages; from (iv) decline, the organization can either demise or enter revival stage; and from (v) revival stage, the organization enters growth stage.

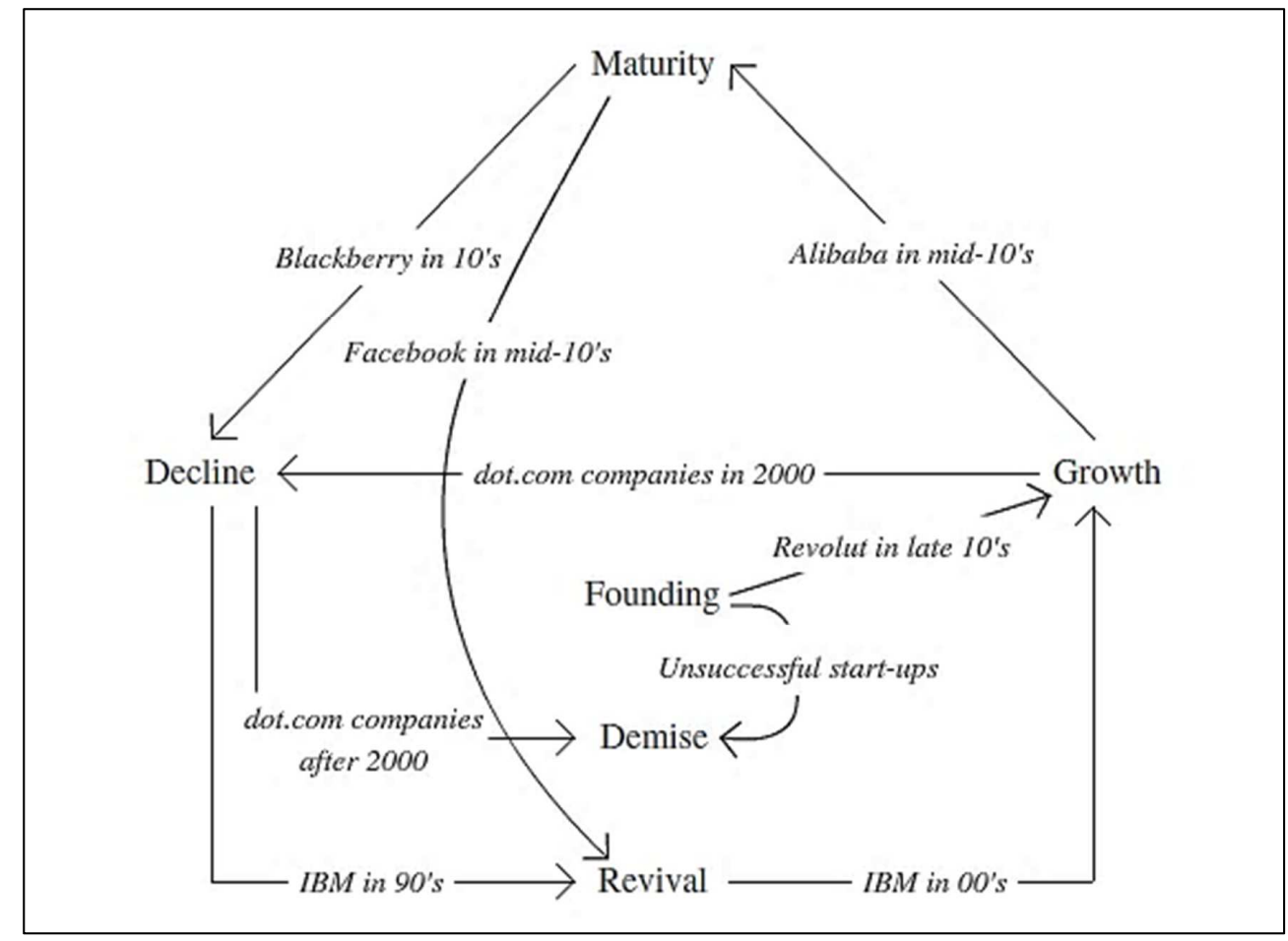

Figure 1 - Proposed Life Cycle Model - Paths Between Stages 


\section{LIMITATIONS AND FUTURE AGENDA}

In our review, we focus on traditional organizational life cycle models. The theory itself has not developed much since its golden age in 70's and 80's (Dufour, Steane and Corriveau, 2018), yet it is possible that our traditionally conducted review may miss some recent studies that would enrich our perspective. Despite that, we believe that we present a concise picture of the organizational life cycle theory.

From our perspective, organizational life cycle theory offers a perspective on how to look on generic states of organizations that can enrich other streams of literature rather than a self-sustained analytical tool. Studies that attempt to empirically assess theoretical organizational life cycle models are rather scarce, questionable in methodology from today's perspective, or offer only partial support (e.g., Drazin and Kazanjian, 1990). This is from our point of view another of the major reasons why the theory is often neglected nowadays - it appears that its assumptions are not supported by real-life evidence. However, it is important to note that it went through its golden age when cross-sectional studies flourished, and that is a major contrast to its rather longitudinal nature (one of the exceptions is the seminal work of Miller and Friesen, 1984). We believe that an assessment using current empirical methods may paint a much different picture.

In our work, we offer several propositions that should be further empirically tested and can be used to infer assumptions about organizational development over time. As we already noted in the introduction and on other places in our review, since a life cycle stage - in which the organization currently is - affects its behavior (La Rocca, La Rocca and Cariola, 2011; Bellone et al., 2008), we consider it particularly fruitful for the field of behavioral strategy (Powell, Lovallo and Fox, 2011). Another interesting research agenda is linking firm behavior to the industry life cycle, as proposed in terms of break-even timing in the organizational life cycle. We believe that more of such contingencies are likely to exist.

\section{CONCLUSION}

In this review, we summarize major studies of the organizational life cycle theory. We agree that five major stages can be distinguished in the organizational life cycle: (i) founding; (ii) growth; (iii) maturity; (iv) revival; and (v) decline. We propose that growth and formalism should be considered to be major characteristics for distinguishing individual stages and we offer their likely evolution based on reviewed models. Besides that, we also propose likely paths between individual stages. Finally, we discuss limitations of the theory and offer some ideas on its future research agenda. 


\section{ACKNOWLEDGEMENTS}

The research is supported by the Masaryk University research project MUNI/A/0920/2017 Consequences of performance feedback on an individual and a firm level.

\section{REFERENCES}

Adizes, I., 1979. Organizational passages: Diagnosing and treating lifecycle problems of organizations. Organizational Dynamics, 8(1), pp.3-25. https://doi.org/10.1016/0090-2616(79)90001-9.

Bellone, F., Musso, P., Nesta, L. and Quéré, M., 2008. Market selection along the firm life cycle. Industrial and Corporate Change, 17(4), pp.753-777. https://doi.org/10.1093/icc/dtn025.

Brunninge, O., Nordqvist, M. and Wiklund, J., 2007. Corporate governance and strategic change in SMEs: The effects of ownership, board composition and top management teams. Small Business Economics, 29(3), pp.295-308. https://doi.org/10.1007/s11187-006-9021-2.

Burkart, M., Panunzi, F. and Shleifer, A., 2003. Family firms. The Journal of Finance, 58(5), pp.2167-2201. https://doi.org/10.1111/1540-6261.00601.

Churchill, N.C. and Lewis, V.L., 1983. The five stages of small business growth. Harvard Business Review, 61(3), p.30-50.

Dodge, H.R. and Robbins, J.E., 1992. An empirical investigation of the organizational life cycle. Journal of Small Business Management, 30(1), pp.2737. https://doi.org/10.1142/S0218495897000247.

Downs, A., 1967. Inside Bureaucracy: A RAND Corporation Research Study. Long Grove: Waveland Press.

Drazin, R. and Kazanjian, R.K., 1990. A reanalysis of Miller and Friesen's life cycle data. Strategic Management Journal, 11(4), pp.319-325. https://doi.org/10.1002/smj.4250110407.

Dufour, Y., Steane, P. and Corriveau, A.M., 2018. From the organizational lifecycle to "ecocycle": a configurational approach to strategic thinking. Asia-Pacific Journal of Business Administration, 10(2-3), pp.171-183. https://doi.org/10.1108/APJBA-05-2018-0095.

Flamholtz, E.G., 1990. Toward a holistic model of organizational effectiveness and organizational development at different stages of growth. Human Resource Development Quarterly, 1(2), pp.109-127.

Flamholtz, E.G., 1995. Managing organizational transitions: Implications for corporate and human resource management. European Management Journal, 13(1), pp.39-51. https://doi.org/10.1016/0263-2373(94)00056-D. 
Gaibraith, J., 1982. The stages of growth. Journal of Business Strategy, 3(1), pp.70-79. https://doi.org/10.1108/eb038958.

Gray, B., and Ariss, S.S., 1985. Politics and strategic change across organizational life cycles. Academy of Management Review, 10(4), pp.707-723. https://doi.org/10.2307/258040.

Greiner, L.E., 1972. Evolution and revolution as organizations grow. Harvard Business Review, 50(4), pp.37-46.

Hanks, S.H., 1990. The organization life cycle: Integrating content and process. Journal of Small Business Strategy, 1(1), pp.1-12.

Hanks, S.H., Watson, C.J., Jansen, E. and Chandler, G.N., 1994. Tightening the life-cycle construct: A taxonomic study of growth stage configurations in hightechnology organizations. Entrepreneurship Theory and Practice, 18(2), pp.5-29. https://doi.org/10.1177/104225879401800201.

Hellweg, S. and Canals, L.M., 2014. Emerging approaches, challenges and opportunities in life cycle assessment. Science, 344(6188), pp.1109-1113. https://doi.org/10.1126/science.1248361.

Jawahar, I.M. and McLaughlin, G.L., 2001. Toward a descriptive stakeholder theory: An organizational life cycle approach. Academy of Management Review, 26(3), pp.397-414. https://doi.org/10.5465/amr.2001.4845803.

Katz, D. and Kahn, R.L., 1978. The Social Psychology of Organizations. New York: Wiley.

Kazanjian, R.K., 1988. Relation of dominant problems to stages of growth in technology-based new ventures. Academy of Management Journal, 31(2), pp.257-279. https://doi.org/10.5465/256548.

Kimberly, J.R., 1979. Issues in the creation of organizations: Initiation, innovation, and institutionalization. Academy of Management Journal, 22(3), pp.437-457. https://doi.org/10.5465/255737.

La Rocca, M., La Rocca, T. and Cariola, A., 2011. Capital structure decisions during a firm's life cycle. Small Business Economics, 37(1), pp.107-130. https://doi.org/10.1007/s11187-009-9229-z.

Lester, D.L., Parnell, J.A. and Carraher, S., 2003. Organizational life cycle: A five-stage empirical scale. The International Journal of Organizational Analysis, 11(4), pp.339-354. https://doi.org/10.1108/eb028979.

Lippitt, G.L. and Schmidt, W.H., 1967. Crises in a developing organization. Harvard Business Review, 45(6), pp.102-112.

Lyden, F.J., 1975. Using Parsons' functional analysis in the study of public organizations. Administrative Science Quarterly, 20(1), pp.59-70. https://doi.org/10.2307/2392123. 
Miller, D. and Friesen, P.H., 1984. A longitudinal study of the corporate life cycle. Management Science, 30(10), pp.1161-1183. https://doi.org/10.1287/mnsc.30.10.1161.

Mintzberg, H., 1984. Power and organization life cycles. Academy of Management Review, 9(2), pp.207-224. https://doi.org/10.5465/ amr.1984.4277632.

Powell, T.C., Lovallo, D. and Fox, C.R., 2011. Behavioral strategy. Strategic Management Journal, 32(13), pp.1369-1386. https://doi.org/10.1002/smj.968.

Quinn, R.E. and Cameron, K., 1983. Organizational life cycles and shifting criteria of effectiveness: Some preliminary evidence. Management Science, 29(1), pp.33-51. https://doi.org/10.1287/mnsc.29.1.33.

Scott, B.R., 1971. Stages of Corporate Development. Cambridge: Harvard Business School.

Scott, M. and Bruce, R., 1987. Five stages of growth in small business. Long Range Planning, 20(3), pp.45-52. https://doi.org/10.1016/0024-6301(87)900719.

Smith, K.G., Mitchell, T.R. and Summer, C.E., 1985. Top level management priorities in different stages of the organizational life cycle. Academy of Management Journal, 28(4), pp.799-820. https://doi.org/10.5465/256238.

Torbert, W.R., 1974. Pre-bureaucratic and post-bureaucratic stages of organization development. Interpersonal Development, 5(1), pp.1-25.

Verreynne, M.-L. and Meyer, D., 2010. Small business strategy and the industry life cycle. Small Business Economics, 35(4), pp.399-416. https://doi.org/10.1007/s11187-008-9165-3.

\section{ABOUT AUTHORS}

Michal Jirásek - PhD student at the department of Corporate Economy, Masaryk University, Czech Republic, his research interests are behavioral strategy and innovation management. E-mail: mijirasek@mail.muni.cz, author's ORCID: http://orcid.org/0000-0002-0407-4045.

Jan Bílek - a former Master degree student at the department of Corporate Economy, Masaryk University, Czech Republic, his interests lie in the fields of organizational behavior and financial management. E-mail: 405733@mail.muni.cz.

(C) 2018 by the authors. Submitted for possible open access publication under the terms and conditions of the Creative Commons Attribution (CC-BY) license (http://creativecommons.org/licenses/by/4.0/). 